\title{
Faktor-faktor yang mempengaruhi penerimaan retribusi daerah di Kota Jambi
}

\section{Ica Romiyati*; Yulmardi; Adi Bhakti}

\author{
Prodi Ekonomi Pembangunan, Fakultas Ekonomi dan Bisnis, Universitas Jambi \\ *E-mail korespondensi : icaromiyati@gmail.com
}

\begin{abstract}
This study aims to determine the development of the population, economic growth, regional spending, and regional retribution, to determine the effect of population, economic growth and regional spending on regional retribution in the city of Jambi from 2000-2016. The type of data used is secondary data obtained from the Central Statistics Agency (BPS). This research uses descriptive and quantitative analysis methods using multiple regression OLS methods. The results showed the population, economic growth, regional expenditure, and regional retribution increased from 2000-2016. Based on the results of multiple regression OLS methods show the population, economic growth, and regional spending have a significant effect on regional retribution in the city of Jambi in 2000-2016.
\end{abstract}

Keywords: Total population, Economic growth, and Regional expenditures

\begin{abstract}
Abstrak
Penelitian ini bertujuan untuk mengetahui perkembangan jumlah penduduk, pertumbuhan ekonomi, belanja daerah dan retribusi daerah, untuk mengetahui pengaruh jumlah penduduk, pertumbuhan ekonomi dan belanja daerah terhadap retribusi daerah di Kota Jambi periode 2000-2016. Jenis data yang digunakan adalah data sekunder yang diperoleh dari Badan Pusat Statistik (BPS). Dalam penelitian ini digunakan metode analisis deskriptif dan kuantitatif menggunakan regresi berganda metode OLS. Hasil penelitian menunjukkan jumlah penduduk, pertumbuhan ekonomi, belanja daerah dan retribusi daerah mengalami peningkatan dari tahun 2000-2016. Berdasarkan hasil regresi berganda metode OLS menunjukkan jumlah penduduk, pertumbuhan ekonomi dan belanja daerah berpengaruh signifikan terhadap retribusi daerah di Kota Jambi tahun 2000-2016.
\end{abstract}

Kata kunci : Jumlah penduduk, Pertumbuhan ekonomi dan Belanja daerah.

\section{PENDAHULUAN}

Pembangunan ekonomi adalah suatu proses kenaikan pendapatan total dan pendapatan perkapita dengan memperhitungkan adanya pertambahan penduduk disertai dengan perubahan fundamental dalam struktur ekonomi suatu negara dan pemerataan pendapatan bagi penduduk suatu negara. Sedangkan arah dari pembangunan ekonomi adalah mengusahakan agar pendapatan masyarakat dapat tercapai secara optimal dan dengan tingkat pemerataan yang sebaik mungkin. Untuk mencapai hakekat dan arah dari pembangunan ekonomi tersebut, maka pembangunan harus didasarkan pada kekhasan 
daerah yang bersangkutan dengan menggunakan potensi sumber daya manusia, kelembangaan, dan sumber daya fisik yang ada (Raga, 2011).

Pada dasarnya otonomi daerah diberlakukan untuk membantu penyelenggaraan pemerintah pusat terutama dalam penyediaan pelayanan kepada masyarakat dan pelaksanaan program-program pembangunan. Pemerintah daerah dipandang sebagai mitra kerja oleh pemerintah pusat dalam penyelenggaraan tugas tersebut di atas. Prinsip pemberian otonomi daerah adalah pemerintah pusat memberikan kewenangan kepada masing-masing daerah dalam menyelenggarakan pemerintahannya di daerahnya sendiri. Sehubungan dengan hal tersebut, daerah dituntut untuk lebih aktif dalam upaya meningkatkan kemampuan dan kemandiriannya, menggali serta mengembangkan potensi sumber-sumber ekonomi dalam rangka mempercepat pertumbuhan ekonomi di daerahnya. Pada saat ini titik berat pemberian otonomi daerah diberikan kepada pemerintah daerah kabupaten dan kota (Mardiasmo, 2002).

Bila dilihat dari kegagalan perencanaan perekonomian terpusat dimana banyak yang kaya akan sumber daya alam menyatakan tidak puas dengan eksploitasi sumber daya alam daerahnya yang sebagian besar digunakan oleh pemerintah pusat, hal ini menunjukkan suatu proses pembangunan yang kompleks dan penuh ketidakpastian yang tidak mudah dikendalikan dan direncanakan dari pusat (Kuncoro, 2004).

Terdapat dua prinsip atas pengenaan retribusi, yang pertama adalah bahwa mereka yang menerima kenikmatan langsung dari suatu pelayanan harus membayar sesuai dengan kebutuhan mereka. Prinsip kedua adalah pengenaan retribusi berdasarkan kemampuan dari wajib retribusi. Semakin rendah penghasilannya, semakin kecil harga yang dikenakan.

Pengelolaan keuangan daerah berkaitan erat dengan pelaksanaan desentralisasi dalam penyelenggaraan urusan pemerintahan. Melalui pelaksanaan desentralisasi, fungsi pemerintah tertentu dilimpahkan kepada pemerintahan daerah dengan tujuan untuk meningkatkan nilai tambah didalam penyelenggaraan pemerintahan. Pemberlakuan Undang-undang Nomor 32 Tahun 2004 tentang Pemerintahan Daerah dengan essensi kebijakan otonomi daerah yang bergulir dewasa ini merupakan wujud dari kewenangan dalam bidang keuangan daerah. Kebijakan otonomi daerah itu dimaksudkan untuk semakin mendekatkan pemerintahan kepada masyarakatnya agar pelayanan yang diberikan menjadi semakin baik. Menurut Suparmoko (2002), dengan semakin mendekatkannya pemerintahan kepada masyarakat diharapkan pemerintah akan mampu memberikan pelayanan publik yang sesuai dengan kebutuhan masyarakat dibanding bila diformulasikan secara sentralistis.

Otonomi daerah telah membawa implikasi didalam penyelenggaraan tugas daerah. Pelaksanaan desentralisasi dibiayai atas beban Anggaran Pendapatan dan Belanja Daerah (APBD) sehingga pembiayaan pembangunan secara bertahap akan menjadi beban terhadap pemerintah daerah. Keadaan ini akan semakin memperkuat tekanan internal dari keuangan daerah, karena peranan sumbangan dan bantuan pusat dalam pembiayaan pembangunan daerah akan semakin (Jaya, 1996). Bantuan pusat dalam pembiayaan pembangunan hanya akan diberikan untuk menunjang pengeluaran pemerintah, khususnya untuk belanja pegawai dan program-program pembangunan yang hendak dicapai. Untuk mencapai tujuan tersebut, maka diperlukan kesiapan dana (financial) yang relatif cukup besar, sehingga daerah diharapkan mampu menggali berbagai potensi untuk meningkatkan Pendapatan Asli Daerah (PAD). Sumber PAD terdiri dari : (1) pajak daerah, (2) retribusi daerah, (3) bagian lain BUMD, (4) penerimaan 
lain-lain PAD yang sah. Pendapatan asli daerah (PAD) dipandang sebagai salah satu indikator atau kriteria untuk mengukur kemampuan suatu daerah. Semakin besar kontribusi yang diberikan PAD terhadap APBD akan menunjukkan semakin besar kemampuan daerah dalam mengelola pembangunan di daerahnya sendiri dan semakin kecil ketergantungan daerah terhadap pemerintah pusat.

Salah satu komponen didalam penerimaan PAD adalah berasal dari retribusi daerah. Sebagai salah satu komponen sumber PAD, retribusi daerah berfungsi sebagai dana bebas daerah yang dapat digunakan untuk membiayai pengeluaran pembangunan daerah (Suparmoko, 2002). Sebagai instrumen kebijakan fiskal, retribusi daerah mempunyai beberapa kemampuan strategis yang mencerminkan manfaat dari retribusi itu sendiri didalam membantu meningkatkan pertumbuhan ekonomi daerah. Manfaat tersebut adalah (1) retribusi daerah dapat meningkatkan kemampuan penerimaan Pendapatan Asli Daerah (PAD), (2) mendorong laju pertumbuhan ekonomi daerah. Retribusi daerah agar dapat berfungsi secara efisien dan efektif, maka tidak saja perhitungan secara ekonomis dan fisik, namun juga harus didukung oleh peningkatan kesadaran dan peran aktif yang cukup tinggi dari masing-masing orang atau masyarakat sebagai wajib retribusi atau jasa yang telah diperoleh.

Provinsi Jambi memiliki 11 kabupaten/kota sebagai daerah otonom, dimana setiap daerah memiliki karakteristik yang berbeda, seperti lokasi geografis, kontribusi setiap sektor, infrastruktur dan lain sebagainya yang mempengaruhi penerimaan masing-masing daerah. Kota Jambi sebagai Ibu Kota Provinsi Jambi memiliki sumber-sumber retribusi yang banyak karena kegiatan ekonomi, jumlah penduduk lebih tinggi di Kota Jambi. Dalam perkembangannya penerimaan retribusi Kota Jambi mengalami peningkatan selama lima tahun terakhir, menurut data BPS (2017), retribusi Kota Jambi pada tahun 2012 adalah sebesar Rp. 22.936.215.999,00 meningkat 38,29 persen pada tahun 2016 menjadi Rp. 69.965.568.462,49 meningkat sebesar 15,94 persen dari tahun sebelumnya, sehingga rata-rata dalam periode 2012-2016 terjadi peningkatan sebesar 14,15 persen pertahun.

Besar kecilnya penerimaan retribusi daerah sangat bergantung kepada besar kecilnya upaya yang dilakukan oleh pemerintah daerah dalam melakukan pungutan retribusi daerah. Setiap tahun didalam anggaran pemerintahan daerah, ditetapkan target penerimaan retribusi daerah yang harus dicapai. Pencapaian target retribusi daerah akan menjadi salah satu ukuran kinerja keuangan daerah tersebut. Untuk pencapaian secara efektif diperlukan kinerja yang optimal terhadap penerimaan retribusi daerah.

Retribusi daerah juga dipengaruhi oleh pertumbuhan ekonomi, jumlah penduduk, dan Belanja Daerah. Daerah yang pertumbuhan ekonominya positif mempunyai kemungkinan mendapatkan kenaikan. Hal ini seharusnya membuat pemerintah daerah lebih terkonsentrasi pada pemberdayaan kekuatan ekonomi lokal untuk menciptakan pertumbuhan ekonomi. Pertumbuhan ekonomi di Kota Jambi. pada tahun 2012 sebesar 7,05 persen kemudian pertumbuhan ekonomi yang tertinggi yaitu tahun 2016 sebesar 9,45 persen, sehingga rata-rata dalam periode 2012-2016 terjadi sebesar 5,85 persen.

Sementara Jumlah Penduduk Kota Jambi pada tahun 2012 adalah sebanyak 557.321 jiwa dan pada tahun 2016 meningkat 1,27 persen menjadi 583.487 jiwa, sehingga rata-rata dalam periode 2012-2016 sebesar 2,7 persen. Selanjutnya, belanja daerah Kota Jambi terus meningkat dari tahun 2012 sampai 2016, pada tahun 2012 adalah sebesar Rp. 634.022.309.268,89 dan tahun 2016 belanja daerah sebesar Rp. 2.343.187.255.196,80, sehingga rata-rata belanja daerah periode 2012-2016 sebesar 19,59 persen. Kebutuhan 
belanja daerah yang terus meningkat ini, tentunya harus di topang dengan ada peningkatan penerimaan daerah. Namun, perkembangan realisasi penerimaan retribusi daerah di Kota Jambi tahun 2012-2016 bergerak kearah penurunan dalam pencapaian target yang telah ditetapkan. Pada tahun 2012 persentase realisasi sebesar 109,68 persen mengalami kenaikan dan pada tahun 2016 menjadi 99,60 persen, sehingga rata-rata dalam periode 2012-2016 sebesar 14,15 persen. Hal ini sangat disayangkan, dikarenakan retribusi daerah di Kota Jambi merupakan komponen penerimaan PAD yang memberikan peran penting sebagai wujud kemandirian daerah tersebut. Tujuan penelitiaan ini adalah 1) Untuk mengetahui perkembangan jumlah penduduk, pertumbuhan ekonomi, belanja daerah dan retribusi daerah di Kota Jambi periode 2000-2016. 2) Untuk mengetahui pengaruh jumlah penduduk, pertumbuhan ekonomi dan belanja daerah terhadap retribusi daerah di Kota Jambi periode 2000-2016.

\section{METODE}

Penelitian ini menggunakan data sekunder berupa: Data jumlah penduduk, pertumbuhan ekonomi, belanja daerah, dan retribusi daerah di Kota Jambi dan lainnya yang terkait dengan penelitian ini. Data tersebut diperoleh dari berbagai sumber dalam bentuk publikasi dan BPS Kota Jambi serta DISPENDA Kota Jambi. Metode dalam penelitian ini menggunakan analisis deskriptif, yaitu metode analisis yang menguraikan mengenai suatu keadaan atau persoalan yang didukung oleh fakta, sifat-sifat serta hubungan antara fenomena yang dianalisis. Penulis juga menganalisis data-data yang diperoleh secara kuantitatif dalam bentuk angka-angka. Untuk melihat pengaruh jumlah penduduk, pertumbuhan ekonomi dan belanja daerah terhadap retribusi daerah di Kota Jambi dalam hal ini menggunakan model regresi berganda, dengan rumus sebagai berikut (Eravimi, 2003).

$Y=\beta_{0}+\beta_{1} X_{1}+\beta_{2} X_{2}+\beta_{3} X_{3}+e$

Keterangan :

Y : Retribusi daerah

$\beta_{0}$ : Konstanta

$\beta_{1}$ : Koefisien regresi jumlah penduduk

$\beta_{2}$ : Koefisien regresi pertumbuhan ekonomi

$\beta_{3}$ : Koefisien regresi belanja daerah

$\mathrm{X}_{1}$ : Jumlah penduduk

$\mathrm{X}_{2}$ : Pertumbuhan ekonomi

$\mathrm{X}_{3}$ : Belanja daerah

e : error (pengganggu)

\section{Uji statistik}

Untuk mendapatkan nilai baku koefisien regresi yang propesional maka setiap variabel bebas, baik secara terpisah maupun secara bersama-sama terhadap variabel terikat dengan cara melakukan analisis regresi berganda dimana dari hasil regresi berganda akan di peroleh besarnya koefisien masing-masing variabel. Dari besarnya variabel masing-masing ini dapat dilihat ada atau tidak adanya pengaruh antara variabel bebas dengan variabel terikat. Pengujian statistik ini dilakukan dengan menggunakan tahap-tahap sebagai berikut : 


\section{Uji F}

Uji ini dimaksud untuk menunjukkan signifikansi pengaruh variabel-variabel bebas secara bersama-sama terhadap variabel terikat. Nilai f hitung yang di dapat kemudian dibandingkan dengan nilai $\mathrm{f}$ tabel pada derajad kebebasan dengan tingkat keyakinan tertentu dengan keputusan dimana jika $\mathrm{H}_{0}$ diterima dan $\mathrm{H}_{1}$ ditolak maka persamaan tersebut tidak signifikan apabila $\mathrm{f}$ hitung $<\mathrm{f}$ tabel, sedangkan jika $\mathrm{H}_{0}$ ditolak dan $\mathrm{H}_{1}$ diterima maka persamaan tersebut signifikan apabila $\mathrm{f}$ hitung $>\mathrm{f}$ tabel.

\section{Uji t}

Uji t dilakukan untuk mengetahui apakah variabel independen secara individual mempengaruhi variabel dependennya dengan menggunakan program eviews 8 . Nilai $t$ hitung dapat diperoleh dengan formula sebagai berikut :

Dimana :

$$
\mathrm{t}=\frac{\beta i-\beta}{S b}
$$

$\beta i$ : Koefisien variabel independen ke-i

$\beta$ : Nilai hipotesis nol

$\mathrm{Sb}$ : simpangan baku (standar deviasi) dari variabel independen ke-i

\section{Analisis koefisien determinasi ganda $\left(\mathbf{R}^{2}\right)$}

Merupakan suatu ukuran yang menunjukkan besarnya sumbangan dari variabelvariabel bebas yang mempunyai pengaruh terhadap variabel terikat. $\mathrm{R}^{2}$ dapat dipakai sebagai ukuran ketetapan atau kecocokan sesuai garis regresi yang ditetapkan sebagai suatu kelompok data. Makin besar nilai $\mathrm{R}^{2}$ berkisar antara 0 sampai 1 berarti ada kecocokan yang sempurna. Bila $\mathrm{R}^{2}=0$ maka tidak ada hubungan antara variabel bebas dengan variabel terikat

\section{Uji asumsi klasik}

\section{Uji multikolineritas}

Uji multikolineritas adalah hubungan linier antara variabel independen di dalam regresi. Masalah multikolineritas muncul jika terdapat hubungan yang sempurna atau pasti diantara variabel atau semua variabel independen dalam model. Pada kasus multikolineritas yang serius, koefisien regresi tidak lagi menunjukkan pengaruh murni dari variabel independen.

\section{Uji autokorelasi}

Autokorelasi adalah keadaan dimana terjadinya korelasi residual untuk pengamatan satu dengan pengamatan yang lain yang disusun menurut runtut waktu. Pengujian terhadap adanya fenomena autokorelasi dalam data yang dianalisis dapat dilakukan dengan menggunakan Durbin-watson test (Priyatno, 2013).

\section{Uji heterokedastisitas}

Dalam regresi linier berganda salah satu asumsi yang harus dipenuhi agar taksiran parameter dalam model tersebut bersifat BLUE (best linier unbiased estimator), untuk mendeteksi gejala heterokedastisitas dalam model regresi pada penelitian ini digunakan uji heterokedastsitas dengan metode white. 


\section{HASIL DAN PEMBAHASAN}

\section{Perkembangan jumlah penduduk, pertumbuhan ekonomi, belanja daerah dan retribusi daerah di Kota Jambi}

Retribusi Daerah adalah pungutan daerah sebagai pembayaran atas jasa atau pemberian izin tertentu yang khusus disediakan dan diberikan oleh pemerintah daerah untuk kepentingan pribadi atau badan (Yani Ahmad, 2002). Menghitung penerimaan retribusi daerah Kota Jambi pada tahun 2000-2016 menggunakan data sekunder. Salah satu masalah yang harus diperhatikan dalam proses pembangunan adalah masalah kependudukan yang mencakup antara lain mengenai jumlah komposisi dan distribusi penduduk. Dalam proses dan kegiatan pembangunan merupakan faktor yang sangat dominan, karena bukan saja berperan sebagai pelaksana tetapi juga menjadi sasaran pembangunan itu sendiri. Oleh karena itu untuk menunjang keberhasilan pembangunan, permasalahan penduduk tidak saja diarahkan pada upaya peningkatan kualitas sumber daya manusia. Berdasarkan tabel 1 terlihat bahwa perkembangan jumlah penduduk dari tahun 2000-2016 mengalami peningkatan. Rata-rata perkembangan jumlah penduduk di Kota Jambi dari tahun 2000-2016 adalah sebesar 2,7 persen menjadi 379.168 jiwa tahun 2000. Perkembangan jumlah penduduk Kota Jambi tahun 2001 menurun sebesar 0,99 persen menjadi 382.939 jiwa. Jumlah penduduk tahun 2002 meningkat sebesar 7,64 persen, tahun 2003 mengalami penurunan sebesar 1,69 persen.

Perkembangan jumlah penduduk Kota Jambi tahun 2004 meningkat sebesar 4,13 persen, Tahun 2005 menurun sebesar 2,36 persen. Pada tahun 2015 retribusi daerah Kota Jambi menurun lagi sebesar 0,86 persen, sedangkan yang paling tertinggi terjadi pada tahun 2008 yaitu sebesar 10,05 persen. Ini merupakan perkembangan jumlah penduduk Kota Jambi semakin tahun semakin bertambah jumlah penduduknya, kenaikan jumlah penduduk setiap tahun menjadi salah satu penyebab bertambahnya jumlah penduduk adalah tingginya tingkat kelahiran. Gambaran yang jelas tentang jumlah penduduk kota jambi selama tahun 2000-2016 dapat dlihat pada tabel 1.

Tabel 1. Jumlah penduduk di Kota Jambi Tahun 2000-2016

\begin{tabular}{ccc}
\hline Tahun & Jumlah Penduduk (Jiwa) & Perkembangan (\%) \\
\hline 2000 & 379.168 & - \\
2001 & 382.939 & 0,99 \\
2002 & 412.219 & 7,64 \\
2003 & 419.197 & 1,69 \\
2004 & 436.539 & 4,13 \\
2005 & 446.872 & 2,36 \\
2006 & 452.566 & 1,27 \\
2007 & 470.902 & 4,05 \\
2008 & 523.572 & 10,05 \\
2009 & 532.743 & 1,75 \\
2010 & 532.881 & 0,02 \\
2011 & 545.193 & 2,31 \\
2012 & 557.321 & 2,22 \\
2013 & 569.934 & 2,26 \\
2014 & 571.062 & 0,19 \\
2015 & 576.067 & 0,86 \\
2016 & 583.487 & 1,27 \\
\hline \multicolumn{3}{c}{}
\end{tabular}

Sumber : Badan Pusat Statistik Kota Jambi, 2017(diolah) 
Pertumbuhan Ekonomi merupakan salah satu dasar yang digunakan oleh pemerintah dalam menentukan atau menyusun kebijakan dalam pembangunan ekonomi, salah satu indikator yang digunakan untuk melihat keberhasilan pembangunan atau pertumbuhan ekonomi adalah dengan melihat perkembangan PDRB. Pertumbuhan ekonomi yang baik adalah pertumbuhan yang merata dan berkesinambungan. Ini berarti tingkat pertumbuhan ekonomi merupakan tolak ukur keberhasilan pembangunan suatu Negara dengan pemanfaatan modal yang dimiliki secara efektip dan efisien. Pertumbuhan ekonomi yang tinggi tidak menjamin terciptanya tujuan diatas (Sukirno, Sadono, 2003). Berdasarkan tabel 2 perkembangan pertumbuhan ekonomi di Kota Jambi pada tahun 2000-2016 mengalami fluktuasi. Dilihat bahwa 2002 pertumbuhan ekonomi kota jambi adalah sebesar 5,85 persen ini merupakan laju peningkatan yang terkecil selama periode analisis. Hal ini disebabkan oleh adanya sektor pertambangan dan penggalian mengalami penurunan yang cukup tinggi sedangkan pada tahun sebelumnya sektor ini mengalami peningkatan yang cukup tinggi.

Pada tahun 2003 pertumbuhan ekonomi Kota Jambi meningkat dibandingkan dengan tahun sebelumnya menjadi sebesar 4,85 persen ini merupakan peningkatan terkecil selama periode analisis. Pada tahun 2004 pertumbuhan ekonomi Kota Jambi meningkat sebesar 5,16 persen, tahun 2005 meningkat lagi sebesar 5,69 persen. Pada tahun 2006 pertumbuhan ekonomi Kota Jambi meningkat sebesar 5,93 persen, tahun 2007 meningkat sebesar 7,16 persen. Tahun 2008 pertumbuhan ekonomi Kota Jambi menurun dibandingkan dengan tahun sebelumnya menjadi 6,14 persen dan tahun 2010 meningkat lagi sebesar 6,55 persen. Pada tahun 2011 pertumbuhan ekonomi Kota Jambi meningkat sebesar 7,08 persen, tahun 2012 pertumbuhan ekonomi menurun dibandingkan dengan tahun sebelumnya menjadi sebesar 7,05 persen.

Pada tahun 2013 pertumbuhan ekonomi meningkat menjadi sebesar 7,76 persen, pada tahun 2014 menurun sebesar 6,38 persen kemudian pada tahun 2015 meningkat sebesar 3,83 persen. Pada tahun 2016 pertumbuhan ekonomi Kota Jambi meningkat menjadi sebesar 10,45 persen, peningkatan yang terjadi pada tahun 2016 merupakan peningkatan yang tertinggi selama periode analisis, hal ini disebabkan oleh adanya peningkatan yang cukup tinggi dari sektor bangunan, sektor jasa-jasa dan sektor pertanian.. Untuk mengetahui gambaran pertumbuhan ekonomi di Kota Jambi kurun waktu 2000-2016 dapat dilihat dari Tabel 2.

Tabel 2. Pertumbuhan ekonomi Kota Jambi Tahun 2000-2016

\begin{tabular}{ccc}
\hline Tahun & PDRB $(\mathbf{R p})$ & Perkembangan $(\boldsymbol{\%})$ \\
\hline 2000 & 1.970 .944 & - \\
2001 & 2.074 .956 & 5,28 \\
2002 & 2.151 .398 & 3,68 \\
2003 & 2.255 .715 & 4,85 \\
2004 & 2.372 .027 & 5,16 \\
2005 & 2.506 .910 & 5,69 \\
2006 & 2.655 .444 & 5,93 \\
2007 & 2.845 .549 & 7,16 \\
2008 & 3.020 .126 & 6,14 \\
2009 & 3.215 .391 & 6,47 \\
2010 & 3.426 .028 & 6,55 \\
\hline
\end{tabular}


Jurnal Paradigma Ekonomika Vol.14.No.2, Juni - Desember 2019 ISSN: 2085-1960 (print); 2684 -7868 (online)

\begin{tabular}{lcc}
\hline 2011 & 3.668 .601 & 7,08 \\
2012 & 3.927 .352 & 7,05 \\
2013 & 4.232 .247 & 7,76 \\
2014 & 4.502 .381 & 6,38 \\
2015 & 4.674 .816 & 3,83 \\
2016 & 5.163 .127 & 10,45 \\
\hline & Rata-rata & $\mathbf{5 , 8 5}$ \\
\hline
\end{tabular}

Sumber: Badan Pusat Statistik Kota Jambi, 2017(diolah)

Belanja daerah dimaksudkan pada Undang-Undang ini sebagai semua kewajiban daerah yang diakui sebagai pengurang nilai kekayaan bersih dalam periode tahun bersangkutan. Rinciannya bisa dibagi dalam dua bentuk yaitu berdasarkan sifat dan berdasarkan fungsinya. Berdasarkan sifat ekonominya belanja daerah terdiri dari belanja pegawai dan belanja barang, subsidi, hibah dan bantuan sosial. Sedangkan besar fungsinya belanja daerah terdiri dari belanja untuk pembangunan perumahan dan fasilitas umum, peningkatan kesehatan, pariwisata, budaya, agama, pendidikan serta perlindungan sosial, berikut perkembangan belanja daerah pada Tabel 3 .

Berdasarkan tabel 3 perkembangan belanja daerah Kota Jambi selama periode 20002016 mengalami fluktuasi. Perkembangan tertinggi terjadi pada tahun 2001 sebesar 66,37 persen yaitu dari Rp 155,345,947,145.61 ini merupakan perkembangan belanja daerah tertinggi selama periode analisis. Perkembangan belanja daerah Kota Jambi pada tahun 2002 menurun menjadi sebesar 21,30 persen. Pada tahun 2003 belanja daerah meningkat lagi sebesar 35,77 persen, tahun 2004 belanja daerah yaitu sebesar 6,49 persen kemudian tahun 2005 meningkat sebesar 40,25 persen hal ini membuktikan bahwa meningkatnya efisiensi pemerintah dalam mengolah belanja daerah.

Pada tahun 2008 belanja daerah Kota Jambi sebesar 0,08 persen ini merupakan belanja daerah yang terkecil dari tahun sebelumnya, meningkat sebesar 9,47 persen tahun 2009, tahun 2010 dan 2011 ini mengalami penurunan pada belanja daerah kota jambi. Pada tahun 2012 sebesar 6,14 persen tahun 2013 meningkat sebesar 34,51 persen kemudian tahun 2014 menurun lagi sebesar 29,70 persen dan tahun 2015 lebih banyak lagi menurun menjadi sebesar 4,70 persen, tahun 2016 meningkat sebesar 38,31 persen, rata-rata belanja daerah Kota Jambi selama periode 2000-2016 yaitu sebesar 19,59 persen.

Tabel 3. Perkembangan belanja daerah di Kota Jambi Tahun 2000-2016

\begin{tabular}{ccc}
\hline Tahun & Belanja Daerah $($ Rp) & Perkembangan $(\%)$ \\
\hline 2000 & $52.229 .214 .581,70$ & - \\
2001 & $155.345 .947 .145,61$ & 66,37 \\
2002 & $197.400 .586 .715,33$ & 21,30 \\
2003 & $307.377 .583 .622,30$ & 35,77 \\
2004 & $328.745 .693 .921,11$ & 6,49 \\
2005 & $550.231 .552 .012,53$ & 40,25 \\
2006 & $520.450 .803 .258,64$ & 5,72 \\
2007 & $601.214 .658 .344,27$ & 13,43 \\
2008 & $601.714 .249 .404,79$ & 0,08 \\
2009 & $664.683 .319 .315,51$ & 9,47 \\
2010 & $670.552 .803 .543,78$ & 0,87 \\
2011 & $673.011 .216 .164,92$ & 0,36 \\
2012 & $634.022 .309 .268,89$ & 6,14 \\
\hline
\end{tabular}


Jurnal Paradigma Ekonomika Vol.14.No.2, Juni - Desember 2019 ISSN: 2085-1960 (print); 2684 -7868 (online)

\begin{tabular}{lcc}
\hline 2013 & $968.259 .569 .564,89$ & 34,51 \\
2014 & $1.377 .435 .398 .399,50$ & 29,70 \\
2015 & $1.445 .473 .753 .841,26$ & 4,70 \\
2016 & $2.343 .187 .255 .196,80$ & 38,31 \\
\hline \multicolumn{1}{c}{ Rata-rata } & $\mathbf{1 9 , 5 9}$
\end{tabular}

Sumber : Badan Pusat Statistik Kota Jambi, 2017(diolah)

Selain dari pajak, Retribusi Daerah juga mempengaruhi di dalam penerimaan pendapatan asli daerah. Penerimaan retribusi daerah Kota Jambi dipunggut/dikelola oleh beberapa instansi di Kota Jambi. Rata-rata perkembangan retribusi daerah Kota Jambi periode 2000-2016 adalah persen. Berdasarkan tabel 4 dapat dilihat pada realisasi Retribusi Daerah Kota Jambi selama periode 2000-2016 cenderung mengalami peningkatan, kecuali pada tahun 2008 realisasi retribusi daerah Kota Jambi menurun sebesar 0,71 persen. Pada tahun 2000 realisasi penerimaan retribusi daerah Kota Jambi sebesar Rp 5,456,234,775.82 tahun 2001 meningkat sebesar 29,69 persen menjadi Rp 7,760,964,589.50 Realisasi retribusi daerah Kota Jambi tahun 2002 menurun sebesar 19,00 persen, tahun 2003 menurun lagi sebesar 17,80 persen.

Realisasi retribusi daerah Kota Jambi pada tahun 2004 menurun sebesar 11,36 persen, tahun 2005 meningkat sebesar 12,54 persen. Kemudian pada tahun 2006 menurun sebesar 9,44 persen pada tahun 2007 menurun lagi sebesar 4,05 persen. Dilihat dari pencapaian realisasinya, realisasi tahun 2009 lebih tinggi dibandingkan dengan tahun 2008. Pada tahun 2013 retribusi daerah Kota Jambi meningkat sebesar 38,29 persen, ini merupakan peningkatan yang tertinggi selama periode analisis, sedangkan pada tahun 2016 realisasi retribusi daerah Kota Jambi menjadi Rp 69,965,568,462.49 atau mengalami penurunan sebesar 14,15 persen. Perkembangan realisasi retribusi daerah di Kota Jambi periode 2000-2016 dapat dilihat pada Tabel 4. berikut ini :

Tabel 4. Perkembangan retribusi daerah di Kota Jambi Tahun 2000-2016

\begin{tabular}{ccc}
\hline Tahun & Retribusi Daerah (Rp) & Perkembangan (\%) \\
\hline 2000 & $5.456 .234 .775,82$ & - \\
2001 & $7.760 .964 .589,50$ & 29,69 \\
2002 & $9.582 .599 .826,00$ & 19,00 \\
2003 & $11.657 .700 .634,08$ & 17,80 \\
2004 & $13.153 .187 .877,82$ & 11,36 \\
2005 & $15.040 .453 .008,55$ & 12,54 \\
2006 & $16.608 .658 .772,54$ & 9,44 \\
2007 & $17.309 .984 .979,16$ & 4,05 \\
2008 & $17.186 .702 .058,34$ & 0,71 \\
2009 & $18.308 .852 .178,50$ & 6,12 \\
2010 & $20.366 .000 .499,09$ & 10,10 \\
2011 & $22.224 .473 .572,64$ & 8,36 \\
2012 & $22.936 .215 .999,00$ & 3,10 \\
2013 & $37.169 .611 .073,05$ & 38,29 \\
2014 & $59.939 .980 .257,70$ & 37,98 \\
2015 & $58.812 .352 .554,45$ & 1,91 \\
2016 & $69.965 .568 .462,49$ & 15,94 \\
\hline
\end{tabular}

Sumber : Dinas Pendapatan Daerah Kota Jambi, 2017(diolah) 


\section{Analisis faktor-faktor yang mempengaruhi penerimaan retrbusi daerah di Kota Jambi}

Untuk menganalisis tujuan penelitian ketiga faktor-faktor yang mempengaruhi penelitian ini terdapat jumlah penduduk, pertumbuhan ekonomi dan belanja daerah terhadap retribusi daerah di Kota Jambi digunakan model analisis regresi berganda yang perhitungan dibantu oleh E-views 8 sebagaimana yang terlihat pada persamaan berikut :

Untuk melihat pengaruh jumlah penduduk, pertumbuhan ekonomi dan belanja daerah di Kota Jambi digunakan model analisis regresi berganda yang perhitungan di bantu oleh program E-views 8 sebagaimana yang terlihat pada persamaan Tabel 5 . Berdasarkan Tabel 5 menunjukkan bahwa persamaan regresi pengaruh jumlah penduduk, pertumbuhan ekonomi dan belanja daerah terhadap retribusi daerah di Kota Jambi

Tabel 5. Regresi penerimaan retribusi daerah di Kota Jambi

\begin{tabular}{lrlrr}
\hline \multicolumn{1}{c}{ Variable } & Coefficient & Std. Error & t-Statistic & Prob. \\
\hline \multicolumn{1}{c}{ C } & $-1.67 \mathrm{E}+12$ & $7.46 \mathrm{E}+11$ & -2.235842 & 0.0435 \\
X1 & 4637917. & 1760129. & 2.634988 & 0.0206 \\
X2 & 232082.4 & 37613.41 & 6.170203 & 0.0000 \\
X3 & 0.009461 & 0.004195 & 2.255349 & 0.0420 \\
\hline R-squared & 0.981211 & Mean dependent var & $2.49 \mathrm{E}+12$ \\
Adjusted R-squared & 0.976875 & S.D. dependent var & $1.96 \mathrm{E}+12$ \\
S.E. of regression & $2.98 \mathrm{E}+11$ & Akaike info criterion & 55.88017 \\
Sum squared resid & $1.15 \mathrm{E}+24$ & Schwarz criterion & 56.07622 \\
Log likelihood & -470.9814 & Hannan-Quinn criter. & 55.89966 \\
F-statistic & 226.2924 & Durbin-Watson stat & 1.377476 \\
Prob(F-statistic) & 0.000000 & & \\
Sumber: Data & & & \\
\end{tabular}

Sumber: Data diolah, 2018

\section{Analisis statistik}

Untuk mengetahui apakah hasil estimasi dapat dipercaya, maka dilakukan pengujian lebih lanjut yaitu uji ekonometrika. Uji tersebut dimaksudkan untuk mengetahui apakah penafsiran-penafsiran terhadap parameter sudah bermakna atau belum secara teoritis dan nyata secara statistik. Dengan demikian, maka dilakukan pengujian variabel-variabel secara simultan (uji F), uji Parsial (uji T) dan koefisien determinasi $\left(\mathrm{R}^{2}\right)$.

\section{Uji signifikan statistik secara simultan (Uji F)}

Uji F statistik dilakukan untuk melihat pengaruh variabel independen yaitu jumlah penduduk, pertumbuhan ekonomi dan belanja daerah di Kota Jambi secara simultan atau secara bersama-sama terhadap variabel dependen yaitu penerimaan retribusi daerah di Kota Jambi. Berdasarkan hasil regresi simultan melalui program e-views 8 di peroleh Fhitung sebesar 226.2924 pada taraf signifikan $\alpha=1 \%, \alpha=5 \%$ atau $\alpha=10 \%$ dengan derajat kebebasan $(\mathrm{df}=\mathrm{n}-\mathrm{k})=16$. Dengan demikian, F-hitung 226.2924 yang artinya secara bersama-sama variabel jumlah penduduk, pertumbuhan ekonomi dan belanja daerah di Kota Jambi berpengaruh signifikan terhadap retribusi daerah di Kota Jambi dan dilihat dari nilai prob (F-statistik) 0,000000 dengan taraf $\alpha=1 \%, \alpha=5 \%$ atau $\alpha=10 \%$ yang artinya secara bersama-sama variabel jumlah penduduk, pertumbuhan ekonomi dan belanja daerah di Kota Jambi berpengaruh signifikan terhadap penerimaan retribusi daerah di Kota Jambi. 


\section{Uji signifikan statistik secara parsial (Uji t)}

Uji t digunakan untuk menganalisis hipotesis secara parsial (individual) guna mengetahui seberapa besar signifikan atau tidak signifikannya pengaruh masing-masing variabel. Pengujian ini dilakukan dengan membandingkan nilai probabilitas dengan besaran signifikan pada taraf $\alpha=1 \%, \alpha=5 \%$ atau $\alpha=10 \%$. Dengan kriteria pengujian jika nilai probabilitas dari salah satu variabel independen melebihi $\alpha=10 \%$, maka pengaruh variabel independen tidak signifikan sehingga Ho diterima, yang artinya bahwa variabel independen tidak berpengaruh secara parsial terhadap variabel dependen. Sebaliknya, apabila nilai probabilitas dari salah satu variabel independen dengan nilai besaran signifikan pada taraf $\alpha=1 \%, \alpha=5 \%$ atau $\alpha=10 \%$ maka pengaruh variabel independen signfiikan, sehingga Ha diterima yang artinya bahwa variabel independen memiliki pengaruh secara parsial terhadap variabel dependen.

Pada perhitungan yang diperoleh nilai probabilitas untuk variabel independen jumlah penduduk sebesar 0.0206 dan signifikan pada $\alpha=1 \%, \alpha=5 \%$ atau $\alpha=10 \%$ sehingga Ho ditolak. Maka secara parsial, jumlah penduduk berpengaruh signifikan terhadap penerimaan retribusi daerah di Kota Jambi, kemudian diperoleh nilai probabilitas untuk variabel independen pertumbuhan ekonomi sebesar 0.0000 dan signifikan pada $\alpha=1 \%$, $\alpha=5 \%$ atau $\alpha=10 \%$ sehingga Ho ditolak. Maka secara parsial pertumbuhan ekonomi berpengaruh signifikan terhadap retribusi daerah di Kota Jambi. Dari hasil perhitungan yang diperoleh nilai probabilitas untuk variabel independen belanja daerah sebesar 0.0420 dan signifikan pada $\alpha=1 \%, \alpha=5 \%$ atau $\alpha=10 \%$ sehingga Ho ditolak. Maka secara parsial, pertumbuhan ekonomi berpengaruh signifikan terhadap retribusi daerah Kota Jambi.

\section{Koefisien determinasi $\left(\mathbf{R}^{2}\right)$}

Koefisien determinasi dimasukkan untuk mengetahui seberapa besar kontribusi setiap variabel independen terhadap variabel dependen secara bersama-sama. Apabila nilai koefisien determinasi $\left(\mathrm{R}^{2}\right)$ semakin mendekati satu, maka persamaan regresi yang dihasilkan baik untuk mengistimasi nilai variabel dependen. Pada hasil perhitungan dapat dilihat bahwa nilai koefisien determinasi $\left(\mathrm{R}^{2}\right)$ sebesar 0.9812 persen, maka demikian nilai koefisien determinasi tersebut memiliki arti bahwa pengaruh seluruh variabel independen yaitu jumlah penduduk, pertumbuhan ekonomi dan belanja daerah terhadap perubahan nilai variabel dependen yaitu retribusi daerah adalah sebesar 98,12 persen sedangkan sisanya sebesar 1,88 persen dipengaruhi variabel lain yang tidak termasuk dalam penelitian ini.

\section{Uji asumsi klasik}

Uji asumsi klasik dimasukkan untuk mendeteksi ada tidaknya indikasi gejala multikolinieritas, heteroskedastisitas dan autokorelasi. Apabila terjadi penyimpangan terhadap asumsi klasik, maka model dalam penelitian tidak valid. Metode ini memiliki beberapa keunggulan dibandingkan metode lainnya. Metode OLS ini memiliki sifat-sifat yang efisien yaitu varian minimum dan hasil estimasi tidak biasa atau dikenal BLUE (Best Liniear Unbiased Estimator). Hasil estimasi yang demikian hanya akan diperoleh apabila asumsi-asumsi klasik terpenuhi. Pengujian asumsi klasik ini untuk mengetahui apakah dari data yang tersedia layak digunakan dalam proses pengujian hipotesis melalui model regresi berganda atau tidak. 
Tabel 6. Uji multikolinieritas

\begin{tabular}{cccc}
\hline Variable & $\begin{array}{c}\text { Coefficient } \\
\text { Variance }\end{array}$ & $\begin{array}{c}\text { Uncentered } \\
\text { VIF }\end{array}$ & $\begin{array}{c}\text { Centered } \\
\text { VIF }\end{array}$ \\
\hline C & $5.56 \mathrm{E}+23$ & 106.5450 & NA \\
X1 & $3.10 \mathrm{E}+12$ & 147.5364 & 2.881718 \\
X2 & $1.41 \mathrm{E}+09$ & 13.85712 & 6.667680 \\
X3 & $1.76 \mathrm{E}-05$ & 27.22296 & 10.16726 \\
\hline
\end{tabular}

Sumber: Data diolah, 2018

Uji multikolinieritas adalah untuk mengetahui ada tidaknya hubungan linier yang sempurna atau pasti diantara beberapa atau semua variabel yang menjelaskan dari model regresi. Untuk mengetahui indikasi gejala multikolinieritas dapat diketahui dari nilai tolerance dan variance influence factor (VIF). Nilai cuttof yang umum digunakan adalah nilai tolerance diatas 0,10 atau nilai VIF dibawah 10 .

Dari hasil uji multikolinieritas dapat diketahui bahwa model tersebut dua bebas dari masalah multikolinieritas dan satu terdapat masalah multikolinieritas, dapat dilihat nilai VIF yaitu jumlah penduduk, pertumbuhan ekonomi dan belanja daerah $\alpha=10 \%$. Dimana nilai VIF jumlah penduduk (X1) sebesar 2.881718, pertumbuhan ekonomi (X2) sebesar 6.667680 dan belanja daerah (X3) sebesar 10.16726. Dengan demikian dapat disimpulkan bahwa model tersebut dua bebas dari masalah dan satu terdapat masalah multikolinieritas atau ada mengandung korelasi antara variabel independen. Untuk mengetahui indikasi gejala autokorelasi digunakan metode Breuch-Godfrey atau disebut sebagai uji Langrange multiolier yang mana jika probabilitas $>\alpha=1 \%, \alpha=5 \%$ atau $\alpha=10 \%$ maka terindikasi gejala autokorelasi. Dari hasil uji autokorelasi dapat diketahui bahwa model tersebut bebas dari masalah autokorelasi dengan melihat bahwa nilai prob $\mathrm{F}$ (2) sebesar 0.1693. Oleh karena itu p-value $0,1693>\alpha=1 \%, \alpha=5 \%$ atau $\alpha=10 \%$ sehingga Ho diterima dapat disimpulkan model regresi tidak terindikasi adanya gejala autokorelasi.

Tabel 7. Uji autokorelasi

Breusch-Godfrey Serial Correlation LM Test:

\begin{tabular}{lllr}
\hline \hline F-statistic & 1.452574 & Prob. F(2,11) & 0.2755 \\
Obs*R-squared & 3.551743 & Prob. Chi-Square(2) & 0.1693 \\
\hline
\end{tabular}

Sumber: Data diolah, 2018

Uji heterokedastisitas terjadi saat residual dan nilai prediksi mempunyai pola hubungan. Pola hubungan ini tidak hanya sebatas hubungan linier tetapi juga berbeda. Metode uji heterokedastisitas yang digunakan adalah white. Apabila nilai prob F-hitung $>\alpha=1 \%, \alpha=5 \%$ atau $\alpha=10 \%$ maka tidak terindikasi adanya gejala heterokedastisitas.

Dari hasil uji heterokedastisitas dapat diketahui bahwa model tersebut bebas dari masalah heterokedastisitas dengan melihat nilai prob F-hitung sebesar 0.0771 Oleh karena itu nilai $p$-value $0,0771>\alpha=1 \%, \alpha=5 \%$ atau $\alpha=10 \%$ maka Ho diterima sehingga dapat disimpulkan model regresi tidak terindikasi adanya gejala heterokedastisitas. 
Tabel 8. Uji heterokedastisitas

Heteroskedasticity Test: White

\begin{tabular}{llll}
\hline \hline F-statistic & 8.299672 & Prob. F(9,7) & 0.0054 \\
Obs*R-squared & 15.54340 & Prob. Chi-Square(9) & 0.0771 \\
Scaled explained SS & 26.68192 & Prob. Chi-Square(9) & 0.0016 \\
\hline \hline
\end{tabular}

Sumber: Data diolah, 2018

\section{KESIMPULAN DAN SARAN}

\section{Kesimpulan}

Perkembangan jumlah penduduk, pertumbuhan ekonomi, belanja daerah dan retribusi daerah di Kota Jambi selama periode 2000-2016 rata-rata jumlah penduduk sebesar 17,29 persen, pertumbuhan ekonomi sebesar 50,17 persen, belanja daerah sebesar 19,59 dan retribusi daerah sebesar 14,15 persen. Dari tiga variabel bebas yang di regres terdapat tiga variabel bebas yang signifikan terhadap retribusi daerah di Kota Jambi. Tiga variabel tersebut yaitu X1 (jumlah penduduk), X2 (pertumbuhan ekonomi) dan X3 (belanja daerah). tiga variabel yang signifikan yaitu X1 (jumlah penduduk) dan X2 (pertumbuhan ekonomi) dan X3 (belanja daerah) terhadap penerimaan retribusi daerah di Kota Jambi.

\section{Saran}

Perkembangan jumlah penduduk, belanja daerah, pertumbuhan ekonomi yang semakin meningkat seharusnya dapat meningkatkan penerimaan retribusi daerah di Kota Jambi. Pemerintah harus mengoptimalkan penerimaan retribusi daerah agar pendapatan daerah semakin meningkat dan menggunakan pendapatan daerah untuk pengeluaran membiayai sektor-sektor yang dianggap produktif. Dalam pengalokasian terhadap belanja daerah, pemerintah lebih spesifik mungkin dalam mengatur pengeluarannya karena setiap pengeluaran yang dikeluarkan maka akan berdampak pada penerimaan APBD, sehingga semakin besar alokasi setiap belanja daerah maka akan berdampak juga pada pembangunan dan pertumbuhan ekonomi masyarakat Kota Jambi. Dalam setiap penerimaan yang diterima oleh pemerintah Kota Jambi dalam belanja daerah itupun tidak luput dari masyarakat, seperti membayar pajak dan retribusi daerah dan taat pada aturan yang diberikan oleh pemerintah Kota Jambi sehingga penerimaan tersebut akan meningkatkan dalam keuangan daerah. Jadi peran masyarakat serta pemerintah harus bekerja sama dalam mewujudkan kesejahteraan masyarakat Kota Jambi, kemudian pemerintah daerah Kota Jambi dirasa perlu mengambil langkah-langkah dalam upaya peningkatan penerimaan retribusi daerah Kota Jambi terutama untuk jenis pungutan/komponen retribusi yang kontribusinya masih kecil dan mengambil langkah yang proaktip dalam mengembangkan sumber-sumber penerimaan retribusi daerah dan sumber lainnya.

\section{DAFTAR PUSTAKA}

Badan Pusat Statistik. (2017). PDRB Kota Jambi. Kota Jambi dalam Angka: Jambi: BPS Eravimi.(2003).Analisis Kontribusi Penerimaan Retribusi Daerah Terhadap Pendapatan Asli Daerah Kota Jambi, Skripsi, Fakultas Ekonomi Universitas Jambi: Jambi.

Priyatno, D. (2013). Analisis Korelasi, Korelasi dan Multivariate dengan SPSS. Gava Media : Yogjakarta.

Jaya, E. (1996). Peraturan Praktis Bagi Penyelenggara Otonomi Daerah, Universitas Indonesaia : Jakarta. 
Kuncoro, M. (2004). Otonomi dan pembangunan Daerah Reformasi, Perencanaan, Strategi dan peluang. Erlangga : Jakarta.

Mardiasmo, (2002). Akuntansi Sektor Publik. Andi : Yogyakarta

Raga, A.W. (2011). Analisis Kinerja Penerimaan Retribusi Pasar di Kabupaten Demak Tahun 2006-2009. Skripsi Tidak Dipublikasikan. Ilmu Ekonomi dan Studi Pembangunan, Fakultas Ekonomi, Universitas Diponegoro : Semarang.

Sukirno, Sadono. 2003. Teori Mikro Ekonomi. Cetakan Keempat Belas. Rajawali Press. Jakarta.

Suparmoko, M. (2002). Ekonomi Politik, untuk Keuangan dan Pembangunan Daerah: Yogjakarta.

Yani, A. (2002). Hubungan Keuangan Antara Pemerintah Pusat dan Daerah di Indonesia. PT. Raja Grafindo Persada : Jakarta.

Aminah, S., \& Parmadi, P. (2018). Dampak Belanja Irigasi dan Jaringan Terhadap Output PDRB Sektor Pertanian dan Pertumbuhan Ekonomi Kota Jambi. Jurnal Paradigma Ekonomika, 13 (1), 7-13

Chandra, D., Syurya, Hidayat.M., \& Rosmeli, R. (2017). Dampak Dana Perimbangan Terhadap Pertumbuhan Ekonomi dan Ketimpangan Antar Daerah di Provinsi Jambi. Jurnal Paradigma Ekonomika, 12 (2), 67-76

Heriberta, H. (2012). Analisis Penerimaan Pajak Penerangan Jalan Kota Jambi 20012009. Jurnal Paradigma Ekonomika, 1(5), 49-55 